\title{
Cytochemical Localization of Mercury in Cryptococcus albidus Grown in the Presence of Mercuric Chloride
}

\author{
By T. A. BROWN AND D. G. SMITH \\ Department of Botany and Microbiology, University College London, \\ London WCIE 6BT
}

(Received 29 October 1976)

INTRODUCTION

Many metals are known to be toxic and, in particular, the harmful effects of mercury compounds on all groups of micro-organisms (Vallee \& Ulmer, 1972), as well as on mammalian systems (Brun et al., 1976), are well documented. However, only two previous investigations on the location of mercury in treated yeast cells have been reported (Brunker \& Bott, 1974; Murray \& Kidby, 1975). Several cytochemical and histochemical techniques have been used to demonstrate mercury by light microscopy, as summarized by Sakai et al. (I975), but there has been only one previous electron microscope study, on rat nervous tissue (Chang \& Hartmann, 1972). This paper describes a simple cytochemical method for the localization of mercury, which is suitable for electron microscopy, and demonstrates the binding sites for mercury within the cells of the yeast Cryptococcus albidus.

\section{METHODS}

Preparation of cultures. Cryptococcus albidus NCYC448 was grown in a liquid medium containing $2.0 \%(\mathrm{w} / \mathrm{v})$ glucose, $0.5 \%(\mathrm{w} / \mathrm{v})$ yeast extract (Oxoid) and $0.21 \%(\mathrm{w} / \mathrm{v}) \mathrm{KH}_{2} \mathrm{PO}_{4}$, final $\mathrm{pH} 5.8$. This medium was sterilized by autoclaving and freshly prepared filtersterilized $\mathrm{HgCl}_{2}$ was added to give a final concentration of $20 \mathrm{mg} \mathrm{Hg}^{2+} \mathbf{1}^{-1}$.

One $\mathrm{ml}$ of an overnight culture of $C$. albidus was inoculated into $25 \mathrm{ml}$ growth medium in a $250 \mathrm{ml}$ side-arm flask, to give a concentration of $10^{5}$ to $2.5 \times 10^{5}$ cells $\mathrm{ml}^{-1}$, and shaken at $20^{\circ} \mathrm{C}$; growth was followed turbidimetrically. Samples for electron microscopy were removed at the start of the exponential phase of growth.

Preparation for electron microscopy. Cells were washed twice in citrate/phosphate buffer, $\mathrm{pH} 5 \cdot 8$, and fixed in $\mathrm{I} \cdot 5 \%(\mathrm{w} / \mathrm{v}) \mathrm{KMnO}_{4}$ at room temperature for $3 \mathrm{~h}$. After two further washes in buffer, a firm pellet was obtained by centrifugation, dehydrated in acetone and embedded in Araldite. Gold sections were examined with a Hitachi HS-9 electron microscope.

Cytochemical technique. Grids with sections were floated section-side down on drops of ammonium hydroxide solution (sp. gr. 0.880 ) for $5 \mathrm{~min}$, washed carefully in distilled water and dried on filter paper.

\section{RESULTS}

The normal ultrastructure of $C$. albidus is shown by a cell grown in the absence of $\mathrm{HgCl}_{2}$ (Fig. Ia). A well-defined nucleus and three mitochondrial profiles can be seen with several pieces of endoplasmic reticulum, part of a vacuole and numerous small vesicles. The cytoplasm is enclosed by the plasmalemma and a rigid wall about $0.1 \mu \mathrm{m}$ thick. 

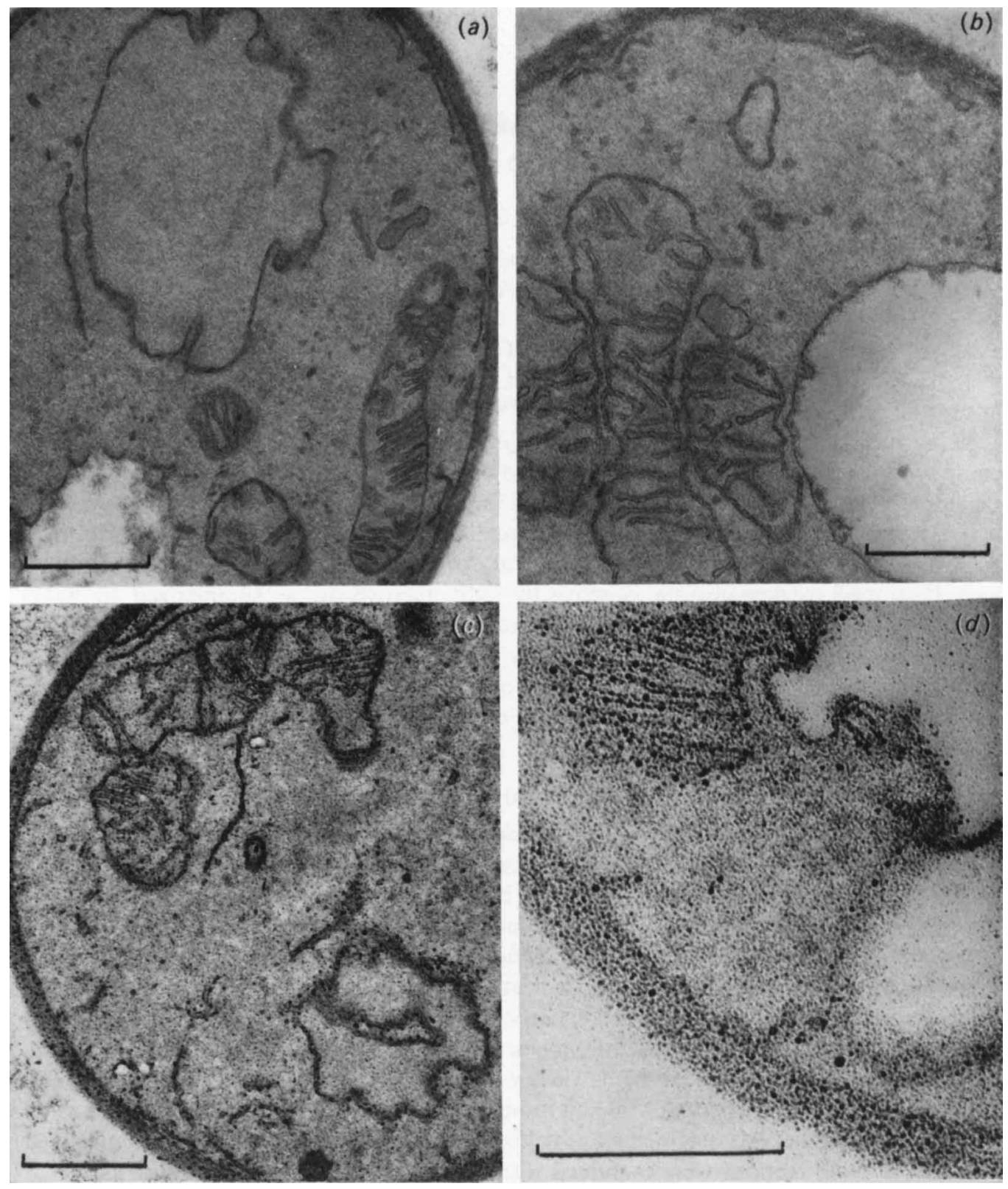

Fig. I. Sections of C. albidus grown: (a) in the absence of $\mathrm{HgCl}_{2} ;(b)$ in the presence of $\mathrm{HgCl}_{2}$, section not treated with $\mathrm{NH}_{4} \mathrm{OH} ;(c, d)$ in the presence of $\mathrm{HgCl}_{2}$, sections treated with $\mathrm{NH}_{4} \mathrm{OH}$. The location of the mercury is shown by electron-opaque granules mainly on membranes. Bar markers represent $0.5 \mu \mathrm{m}$.

Few significant ultrastructural changes occur during early growth in the presence of $\mathrm{HgCl}_{2}$ (compare Fig. I $a, b$ ). However, sections treated with $\mathrm{NH}_{4} \mathrm{OH}$ show electron-opaque granules indicating that mercury is present in various parts of the cell (Fig. I $c, d$ ). These granules are associated mainly with the wall and membranes. Mercury is bound to both the inner and outer mitochondrial and nuclear membranes, to the endoplasmic reticulum 
and to the various vesicles. The presence of granules specifically on the plasmalemma is not so definite, but in Fig. $I(d)$ there is an invagination of the cell membrane and several spots of the cytochemical marker are associated with it. Freeze-etching studies have shown such invaginations to be infoldings of the plasmalemma (Bauer, 1970), so the presence of mercury here may be indicative of its presence elsewhere on the plasmalemma. Few granules are seen in the general cytoplasmic matrix, within the nucleus, or within the vacuole.

Ammonium hydroxide treatment had no effect on cells grown in medium without $\mathrm{HgCl}_{2}$ : such cells had a similar appearance to those in Fig. I (a).

\section{DISCUSSION}

The main problem with cytochemistry is to ensure the specificity of the chemical reaction, in this case for mercury. The reaction between mercuric compounds and $\mathrm{NH}_{4} \mathrm{OH}$ produces an amido derivative with the basic formula $\left(\mathrm{HgNH}_{2} \mathrm{X}\right)_{n}$, where $\mathrm{X}$ is a halide group such as chloride. This compound is made up of long zig-zag molecules of alternating $\mathrm{Hg}$ and $\mathrm{NH}_{2}$ units, with the $\mathrm{X}^{-}$anions between the separate chains (Aylett, 1973):

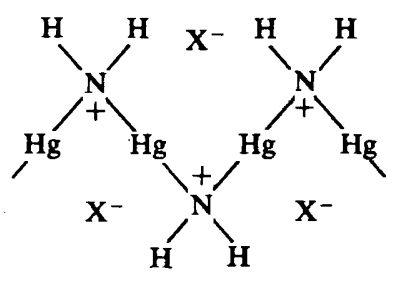

With the concentration of $\mathrm{HgCl}_{2}$ used in our experiments, there is insufficient density of mercury atoms to give enough electron scattering to produce an image in the electron microscope. The formation of the long-chain amido compound draws together separate mercury atoms and this concentration effect gives rise to the electron-opaque granules (Fig. I $c, d$ ). Theoretically reactions resulting in precipitates of sufficient density to be seen under the electron microscope are also possible between $\mathrm{NH}_{4} \mathrm{OH}$ and some other elements but, unlike the mercury-ammonia complex, these are all highly soluble in water and so likely to be removed when the grids are washed following $\mathrm{NH}_{4} \mathrm{OH}$ treatment. The consistent absence of deposits in $\mathrm{NH}_{4} \mathrm{OH}$ treated control cells suggests that this test is specific for mercury under the conditions used.

A similar technique has been described by Chang \& Hartmann (1972), the basis of which is the reaction between mercuric salts and $\left(\mathrm{NH}_{4}\right)_{2} \mathrm{~S}$ leading to the formation of a mercuryammonium-sulphur complex. This reaction is routinely used in inorganic analysis and in the controlled conditions of the test tube is specific for mercuric ions. However, with the less-defined conditions of a yeast cell, it is still necessary to ensure that no reaction occurs in sections of cells grown in the absence of $\mathrm{HgCl}_{2}$ before drawing conclusions on the presence of mercury in treated cells. Another difference between the procedure described here and that of Chang \& Hartmann (I972) involves the stage at which the material is exposed to the reactant. Chang \& Hartmann worked with nervous tissue and immersed the sample in $\left(\mathrm{NH}_{4}\right)_{2} \mathrm{~S}$ immediately after fixation and before dehydration and embedding. The problems involved in the preparation of yeast cells for electron microscopy are well known; the wall forms a barrier to penetration of the reagents and this must also be taken into account with this technique. Because of such difficulties it is probably advisable to use the cyto- 
chemical reagent as a post-stain rather than introducing it during the preparative stages. This precludes the use of copper grids with $\left(\mathrm{NH}_{4}\right)_{2} \mathrm{~S}$ due to the formation of mixed copper sulphides and disintegration of the grid in the electron beam. For these reasons $\mathrm{NH}_{4} \mathrm{OH}$ is recommended for work with yeast cells.

The results obtained using the $\mathrm{NH}_{4} \mathrm{OH}$ technique are consistent with those of Murray \& Kidby (1975) who showed by autoradiography that the major fraction of bound mercury was present in the walls of Saccharomyces cerevisiae treated with lower concentrations of $\mathrm{HgCl}_{2}\left(5^{\circ} \cdot \mathrm{mg} \mathrm{Hg}^{2+} \mathrm{1}^{-1}\right)$ than used in our study. They also found that a small fraction of the mercury was associated with the cytoplasm and showed this to be bound to molecules with a molecular weight greater than 1000 - which is what one would expect if mercury were bound to membranes as suggested here. The affinity of $\mathrm{Hg}^{2+}$ for yeast cell membranes was first suggested by Passow \& Rothstein (1960) who demonstrated that irreversible membrane damage was caused by concentrations of $\mathrm{Hg}^{2+}$ as low as $0.2 \mathrm{mg} \mathrm{l}^{-1}$ and resulted in a loss of $\mathrm{K}^{+}$and other anions to the medium. Mercury has low affinity for membrane phospholipids (Vallee \& Ulmer, 1972) but binds to protein sulphydryl groups and sugar phosphoryl sites, the latter being involved in ion transport (Passow, Rothstein \& Clarkson, 196I).

The presence of mercury on the mitochondrial membranes is interesting as $\mathrm{Hg}^{2+}$ ions have been implicated in inhibiting ATP-driven NAD reduction by succinate in phosphorylating beef heart submitochondrial particles (Schuurmans-Stekhoven, Sani \& Sanadi, 1970), and in inducing proton release in complete beef heart mitochondria(Southard, Blondin \& Green, 1974).

The wall binding sites were suggested by Murray \& Kidby (1975) to be glucan-linked proteins and this study throws no further light on this. The present state of knowledge on the organization of the cell wall of yeasts is still somewhat rudimentary but what is known, especially concerning the role of glucan in cross-wall formation during budding (Matile, Moor \& Robinow, 1969), may be useful in future studies using the cytochemical technique.

There are numerous other possible binding sites for mercury in the cell, notably nucleic acids (Vallee \& Ulmer, 1972), and the affinity of mercury for sulphydryl groups provides a means of binding to any protein with free $\mathbf{S H}$ groups. This may explain why the electron micrographs of yeasts grown in higher concentrations (100 $\mathrm{mg} \mathrm{Hg}^{2+} 1^{-1}$ ) of $\mathrm{HgCl}_{2}$ than used in this study (Brunker \& Bott, 1974) appear to show mercury present in most parts of the cell.

The cytochemical technique described here provides a simple and rapid way of locating mercury in $\mathrm{HgCl}_{2}$-treated cells, and further studies should provide more detailed information on the precise binding sites. Work is in progress with electron microscopic X-ray microanalysis which we hope will confirm the results presented and provide quantitative data on mercury binding in the cell.

One of us (T.A. B.) acknowledges the support of a research studentship from the Science Research Council.

\section{REFEREN CES}

AyLeTt, B. J. (1973). Chemistry of Group II B. In Comprehensive Inorganic Chemistry, vol. III, pp. 187328. Edited by J. C. Bailar, H. J. Emeléus, R. Nyholm and A. F. Trotman-Dickenson. Oxford: Pergamon Press.

BAUER, H. (1970). A freeze-etch study of membranes in the yeast Wickerhamia fluorescens. Canadian Journal of Microbiology 16, 219-222. 
Brun, A., Abdulla, M., Isle, I. \& Samuelsson, B. (I976). Uptake and localisation of mercury in the brain of rats after prolonged oral feeding with mercuric chloride. Histochemistry 47, 23-29.

BRUNKER, R. L. \& BoTT, T. L. (1974). Reduction of mercury to the elemental state by a yeast. Applied Microbiology 27, 870-873.

Chang, L. W. \& Hartman, H. A. (1972). Electron microscopic histochemical study on the localisation and distribution of mercury in the nervous system after mercury intoxication. Experimental Neurology 35, $122-137$.

Matile, Ph., Moor, H. \& Robinow, C. F. (1969). Yeast cytology. In The Yeasts, vol. I, pp. 220-302. Edited by A. H. Rose and J. S. Harrison. London and New York: Academic Press.

MuRRAY, A. D. \& KIDBY, D. K. (1975). Sub-cellular location of mercury in yeast grown in mercuric chloride. Journal of General Microbiology 86, 66-74.

Passow, H. \& RothsteIN, A. (1960). The binding of mercury by the yeast cell in relation to changes in permeability. Journal of General Physiology 43, 621-623.

Passow, H., Rothstein, A. \& Clarkson, T. W. (1961). The general pharmacology of the heavy metals. Pharmacological Reviews 13, 185-224.

SAKal, K., OKABE, M., ETo, K. \& TAKeUChI, T. (1975). Histochemical demonstration of mercury in human tissue cells of Minamata disease by use of autoradiographic procedure. Acta histochemica et cytochemica $8,257-264$.

SchuUrmans-Stekhoven, F. M. A. H., Sani, B. P. \& Sanadi, D. R. (1970). Energy-linked NAD reduction in phosphorylating submitochondrial particles from heavy-layer beef heart mitochondria. Biochemical and Biophysical Research Communications 39, 1026-1036.

SouthaRd, J. H., BLoNDIN, G. A. \& GREen, D. E. (1974). Induction of trans-membrane proton transfer by mercurials in mitochondria. Journal of Biological Chemistry 249, 678-682.

VAlLeE, B. L. \& Ulmer, D. D. (1972). Biochemical effects of mercury, cadmium and lead. Annual Review of Biochemistry 4I, 9I-128. 